\title{
Mouse Cachexia Induced by Trehalose Dimycolate from Nocardia asteroides
}

\author{
By CÉLIO L. SILVA, ${ }^{1}$ IZAIRA TINCANI, ${ }^{1}$ \\ SEBASTIÃO L. BRANDÃO FILHO ${ }^{1}$ AND LUCIA H. FACCIOLI ${ }^{2}$ \\ ${ }^{1}$ Department of Parasitology, Microbiology and Immunology, and ${ }^{2}$ Department of \\ Pharmacology, School of Medicine of Ribeirão Preto, University of São Paulo, 14.049 Ribeirão \\ Preto, SP, Brazil
}

(Received 21 December 1987)

Trehalose dimycolate (TDM) isolated from Nocardia asteroides induced in mice a severely wasted condition known as cachexia. Intraperitoneal injection of mice with five $10 \mu \mathrm{g}$ doses of TDM in mineral oil at intervals of $2 \mathrm{~d}$ killed $90 \%$ of the animals within $26 \mathrm{~d}$. Death followed a precipitous weight loss and an inflammatory process in the peritoneal cavity. When mice were injected intraperitoneally with a single $10 \mu \mathrm{g}$ dose of TDM, $48 \mathrm{~h}$ later, they had begun to lose weight and exhibited extreme hypertriglyceridaemia and hypoglycaemia. Tumour necrosis factor (or cachectin) was detected in the plasma from animals injected with TDM. This cytokine released by mononuclear phagocytes may be involved in the induction of cachexia by TDM.

\section{INTRODUCTION}

Trehalose dimycolate (TDM) is one of the products of mycobacteria (see Stewart-Tull, 1983, for a review) that enhances the nonspecific resistance of mice to tumours and to bacterial infections (Bekierkunst et al., 1971; Leclerc et al., 1976; Yarkoni et al., 1978; Parant et al., 1977). Mycobacterial TDM also exerts a toxic effect in experimental animals, leading to cachexia and death (Bloch, 1950). Since the discovery of the toxic TDM from the tubercle bacillus, TDMs have been isolated from strains of Corynebacterium (Thomas et al., 1979; Ioneda \& Silva, 1979), Rhodococcus (Silva et al., 1979) and Nocardia (Silva et al., 1979). However, little is known about the biological properties of TDM isolated from Nocardia. Since the chain length of the mycolic acid in TDM from Nocardia is only about 56 carbon atoms (Silva et al., 1979), while it is about 80 carbon atoms in mycolic acids in TDM from mycobacteria, it seemed important to verify whether TDM isolated from $N$. asteroides would have a toxic effect in mice. The possible role of tumour necrosis factor (TNF) in TDM-induced cachexia is discussed.

\section{METHODS}

Bacterial strain and culture conditions. Nocardia asteroides was obtained from a nocardiosis patient at the Clinical Hospital of Ribeirão Preto, University of São Paulo, Brazil, and was maintained on Sabouraud's dextrose agar. It was cultured at $37^{\circ} \mathrm{C}$ for $15 \mathrm{~d}$ in medium containing $10 \mathrm{~g}$ yeast extract, $10 \mathrm{~g}$ glucose and $1 \mathrm{~g} \mathrm{NaCl}$ per litre of distilled water.

Lipid extraction. Bacteria were autoclaved, harvested by centrifugation at $5000 \mathrm{~g}$ for $5 \mathrm{~min}$ and washed five times with $100 \mathrm{ml}$ distilled water. Lipids were extracted from the killed cells $(10 \mathrm{~g}$ dry weight) in $300 \mathrm{ml}$ chloroform/methanol $(2: 1, \mathrm{v} / \mathrm{v})$ by stirring at room temperature for $2 \mathrm{~h}$. The extract was separated by centrifugation at $5000 \mathrm{~g}$ for $10 \mathrm{~min}$ and the pellet, suspended in the same solvent mixture as described above, was re-extracted three more times as described. The combined extracts were dried on a rotary evaporator and extracted with diethyl ether as described by Silva \& Ioneda $(1977 a)$ to eliminate non-lipid residues. Briefly, the re-extraction was done by adding 1 vol. $1 \mathrm{M}-\mathrm{NaCl}$ and 5 vols diethyl ether. The ethyl ether phase was washed with distilled water, dried over anhydrous $\mathrm{Na}_{2} \mathrm{SO}_{4}$, filtered and concentrated under reduced pressure.

Abbreviations: TDM, trehalose dimycolate; TNF, tumour necrosis factor. 
Fractionation of lipid extract and purification of TDM. The glycolipid TDM was obtained by a method used previously (Silva et al., 1979). Briefly, the lipid extract, dissolved in a small volume of chloroform, was loaded on a column $(2.1 \times 28.0 \mathrm{~cm})$ of silicic acid/silica gel $\mathrm{H}(1: 1, \mathrm{w} / \mathrm{w})$ which was successively eluted with $500 \mathrm{ml}$ of each of the following solvents: chloroform; $5 \%(\mathrm{v} / \mathrm{v})$ ethanol in chloroform; and $60 \%(\mathrm{v} / \mathrm{v})$ acetone in chloroform. The $60 \%(\mathrm{v} / \mathrm{v})$ acetone in chloroform fraction was further purified by preparative TLC on plastic sheets coated with silica gel F254 (Merck), using the solvent system chloroform/acetone/methanol/water $(50: 60: 2 \cdot 5: 3$, by vol.), yielding a purified glycolipid that had an $[\alpha]_{5}^{25}$ value of $+47\left(\mathrm{C}=0.5, \mathrm{CHCl}_{3}\right)$ and a melting point of $38^{\circ} \mathrm{C}$. It contained $13 \%$ sugar (determined by the phenol/sulphuric acid method; Dubois et al., 1956) and had an infrared spectrum similar to that described for TDM isolated from Mycobacterium tuberculosis (Kato \& Asselineau, 1971) and from Nocardia asteroides (Silva et al., 1979). After alkaline hydrolysis (Ioneda et al., 1963), trehalose and mycolic acid were identified in the aqueous and ether phases by TLC and paper chromatography (Silva \& Ioneda, $1977 \mathrm{~b}$ ), respectively. Physical and chemical analysis of the isolated mycolic acid showed that the mean carbon chain length was $C_{56}$, in agreement with previous results (Silva et al., 1979).

Animals. Male Swiss mice 4 to 6 weeks old, and weighing 19.0-21.0 g were used.

Toxicity. The TDM to be tested for toxicity was dissolved in mineral oil (Nujol, from Plough Inc.). Before use, the clear solution was heated to $56^{\circ} \mathrm{C}$ and subjected to ultrasonic vibration for $5 \mathrm{~min}$ at $100 \mathrm{~W}$, using a probe of $9 \mathrm{~mm}$ diameter. The toxicity of TDM was evaluated by injecting mice intraperitoneally with different doses in $0.1 \mathrm{ml}$ mineral oil and recording weight loss and deaths. A control group was given $0.1 \mathrm{ml}$ mineral oil alone.

Preparation of plasma. Mice injected with $10 \mu \mathrm{g}$ TDM were exsanguinated $48 \mathrm{~h}$ after TDM injection, and the plasma was obtained. Control plasma was obtained from noninjected mice and from mice injected with mineral oil in a similar manner. All plasma samples were stored at $-20^{\circ} \mathrm{C}$ until used.

Plasma triglyceride and glucose determinations. These were done with triglyceride and glucose kits (Labtest Diagnostica), respectively.

Cytotoxicity assay of TNF. Killing of L929 mouse tumour cells was used to measure the cytotoxicity of soluble factor(s) present in the plasma. This was a standard assay (Ruff \& Gifford, 1980). Briefly, L929 cells in RPMI1640 medium containing $5 \%(\mathrm{v} / \mathrm{v})$ foetal calf serum were seeded at $3 \times 10^{4}$ cells per well in 96-well microtitre plates (Linbro, Flow Laboratories) and incubated overnight at $37^{\circ} \mathrm{C}$ in an atmosphere of air/ $\mathrm{CO}_{2}(95: 5, \mathrm{v} / \mathrm{v})$. Serial $1: 2$ dilutions of plasma were made in the above medium containing $1.0 \mu \mathrm{g}$ actinomycin D (Sigma) $\mathrm{ml}^{-1}$, and the cell culture medium was replaced with $100 \mu \mathrm{l}$ volumes of the dilutions in triplicate. The next day, cell survival was assessed by fixing and staining the cells with crystal violet $(0.2 \%$ in $20 \%$ methanol), solubilizing the stained cells with $0.1 \mathrm{ml} 1 \%(\mathrm{w} / \mathrm{v})$ SDS per well and reading the absorbance of each well at $490 \mathrm{~nm}$ with a model BT-100 Microelisa Autoreader (Bio-Tek). Percentage cytotoxicity was calculated as $\left[1-\left(A_{490}\right.\right.$ of sample $) /\left(A_{490}\right.$ of control)] $\times 100$.

\section{RESULTS}

TDM was injected into mice intraperitoneally at $2 \mathrm{~d}$ intervals (five $10 \mu \mathrm{g}$ doses in $0.1 \mathrm{ml}$ mineral oil), and body weight and mortality were observed for $30 \mathrm{~d}$. Results from a typical experiment are shown in Fig. 1. Mice injected with TDM showed an initial decrease in body weight after the first injection; the animals were reluctant to move, and appeared unwell, with ruffled fur. They had lost $18-26 \%$ of their initial body weight by day 12 after the first injection. In addition to inducing cachexia, TDM also caused the death of $90 \%$ of the animals between 14 and $28 \mathrm{~d}$ after the first injection. Autopsy of the animals injected with TDM showed the presence of peritonitis, with an inflammatory exudate, massive adhesions of the organs in the peritoneal cavity, numerous granulomas and splenomegaly. Control mice given mineral oil alone did not die and showed no toxic effects; they had gained $26 \%$ in body weight by day 30 of the experiment. The results obtained were reproducible in three experiments and the pattern of body weight curves and survival rates were very similar.

Cachexia in chronic diseases in associated with a depressed lipoprotein lipase function, resulting in enhanced triglyceride concentration in plasma and enhanced peripheral glucose oxidation (Gallin et al., 1969; Beisel, 1972; Rouzer \& Cerami, 1980; Beutler \& Cerami, 1986). To examine this effect, mice were injected with $10 \mu \mathrm{g}$ TDM and killed $48 \mathrm{~h}$ later (initial observations showed that $48 \mathrm{~h}$ is sufficient to produce cachexia in mice). The triglyceride concentration in the plasma was elevated $2 \cdot 9$-fold, and the plasma glucose concentration was 2.6 times less, in mice injected with TDM compared with control animals (Fig. 2). Killing of tumour cells in vitro is a sensitive bioassay to detect TNF (Beutler \& Cerami, 1986). Cytotoxic 


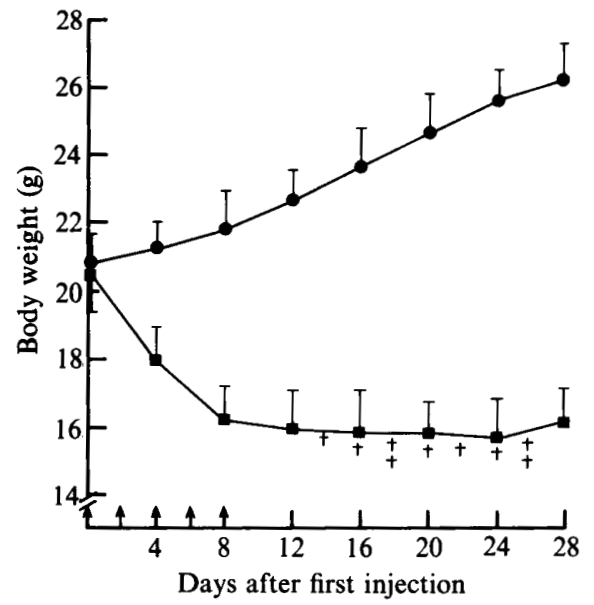

Fig. 1. Mean body weight $( \pm S D)$ of two groups of ten mice at various times after intraperitoneal injection of five $10 \mu \mathrm{g}$ doses of TDM in mineral oil ( $\square$ ) or mineral oil alone ( () ). The mice were injected on the days indicated by arrows. Each cross $(t)$ represents the death of one mouse. It is not possible to examine the results statistically because of the decreasing number of animals in the TDM-injected group. Results are from a typical experiment.

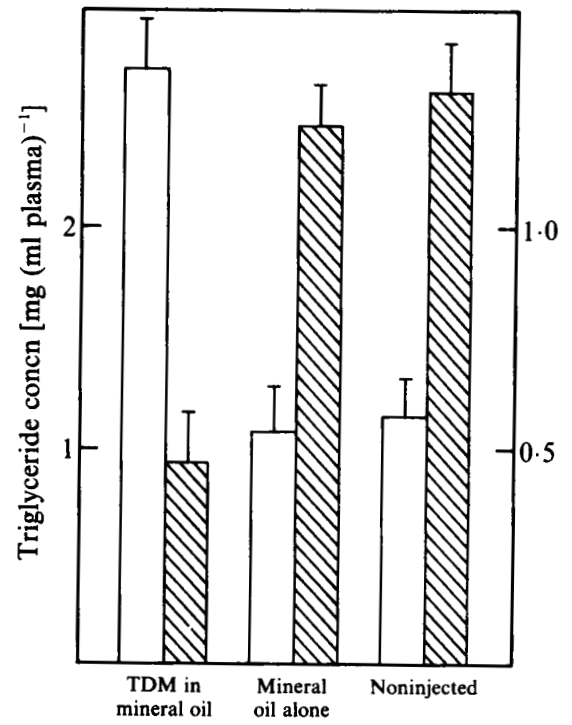

Fig. 2

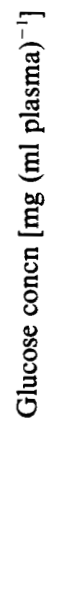

Fig. 2. Plasma triglyceride (open bars) and glucose (hatched bars) concentrations in mice injected intraperitoneally with $10 \mu \mathrm{g}$ TDM in $0.1 \mathrm{ml}$ mineral oil. Plasma samples were obtained $48 \mathrm{~h}$ after injection. Control groups consisted of noninjected mice, and mice injected with mineral oil alone. The data, from a typical experiment, are expressed as mean \pm SD for six mice in each group.

Fig. 3. Cytotoxicity for L929 tumour cells of plasma from mice injected intraperitoneally with $10 \mu \mathrm{g}$ TDM in mineral oil. Plasma samples were obtained $48 \mathrm{~h}$ after injection and diluted 1:128 in RPMI1640 medium. Control groups consisted of noninjected mice, and mice injected with mineral oil alone. The data, from a typical experiment, are expressed as mean \pm SD for six mice in each group.

activity for L929 tumour cells was observed in plasma collected from mice injected $48 \mathrm{~h}$ previously with TDM, but not in plasma collected from animals inoculated with mineral oil or from noninjected animals (Fig. 3). 


\section{DISCUSSION}

Several common physiological and biochemical derangements are seen in the mammalian host responding to a variety of invasive stimuli such as bacterial, viral, and protozoan infections. These responses include a condition known as cachexia in which the animal continuously loses weight, even while consuming an adequate diet. It has been widely supposed that microbial products are directly responsible for the wasting associated with infection (Beutler \& Cerami, 1986). The results presented here show that TDM is one of the bacterial products able to induce cachexia in mice: wasting and ultimately death, as well as hypertriglyceridaemia and depressed plasma glucose levels, all occurred after TDM injection; these are all effects associated with cachexia.

In response to a variety of invasive stimuli, reticuloendothelial cells and lymphocytes secrete cytokines that are capable of altering host metabolism. TNF (or cachectin) is one of these cytokines; it has been implicated as being important in inducing shock (Beutler \& Cerami, 1986) and cachexia (Rouzer \& Cerami, 1980) in animal models, and it causes complete suppression of the enzyme lipoprotein lipase (Torti et al., 1985) thereby preventing the uptake of exogenous triglyceride by fat cells and causing lipaemia (Guy, 1975; Rouzer \& Cerami, 1980). We found that plasma from TDM-treated mice had cytotoxic activity for L929 tumour cells, a specific assay for TNF (Beutler \& Cerami, 1986).

The predominant physiological role of TNF in TDM-treated animals is still unknown. TNF is released by mononuclear cells (Beutler \& Cerami, 1986), and it appears to have many advantages for the host. For instance, it has parasiticidal (Taverne et al., 1981) and tumoricidal activity (Carswell et al., 1975) and it is able to activate neutrophils and increase phagocytosis (Gamble et al., 1986) by stimulating leukocytes to destroy micro-organisms in vitro (Silberstein \& David, 1986), and to mobilize substances rich in energy. Thus, the nonspecific immunopotentiating activity of TDM (Stewart-Tull, 1985) may be related, at least in part, to the release of TNF. However, when TNF is liberated in large amounts, the resulting metabolic derangement will result in cachexia, anorexia, fever and diarrhoea, among other phenomena (Beutler \& Cerami, 1986), frequently resulting in death.

We wish to thank Rosângela C. P. Mesquita for help and secretarial assistance. This investigation was supported by grants from Fundação de Amparo à Pesquisa do Estado de São Paulo (FAPESP - process no. 87/1853-0) and Conselho Nacional de Pesquisa (CNPq - process nos 401007/87.1 and 30.0351/81).

\section{REFERENCES}

BeISEL, W. R. (1972). Interrelated changes in host metabolism during generalized infectious illness. American Journal of Clinical Nutrition 25, 12541260.

Bekierkunst, A., LeviJ, I. S., Yarkoni, E., Vilkas, E. \& LEDERER, E. (1971). Suppression of urethaninduced lung adenomas in mice treated with trehalose 6,6'-dimycolate (cord factor and living Bacillus Calmette Guerin). Science 174, 1240.

Beutler, B. \& Cerami, A. (1986). Cachectin and tumour necrosis factor as two sides of the same biological coin. Nature, London 320, 584-588.

BLOCH, H. (1950). Studies on the virulence of tubercle bacilli. Isolation and biological properties of a constituent of virulent organisms. Journal of Experimental Medicine 91, 197-217.

Carswell, E. A., Old, L. J., Kassel, R. L., Green, S., Fiori, N. \& Williamson, B. (1975). An endotoxininduced serum factor that causes necrosis of tumors. Proceedings of the National Academy of Sciences of the United States of America. 72, 3666-3670.

Dubois, M., Gilles, K. A., Hamilton, J., Rebers, P. A. \& SMITH, F. (1956). Colorimetric method for

determination of sugars and related substances. Analytical Chemistry 28, 350-356.

Gallin, J. I., Kaye, D. \& O'Leary, W. M. (1969). Serum lipids in infection. New England Journal of Medicine 281, 1081-1086.

Gamble, J. R., Harlan, J. M., Klebanoff, S. J. \& VADAS, M. A. (1986). Stimulation of the adherence of neutrophils to umbilical vein endothelium by human recombinant tumor necrosis factor. Proceedings of the National Academy of Sciences of the United States of America 82, 8667-8671.

GuY, M. W. (1975). Serum and tissue fluid lipids in rabbits experimentally infected with Trypanosoma brucei. Transactions of the Royal Society for Tropical Medicine and Hygiene 69, 429.

IONEDA, T. \& SILVA, C. L. (1979). Isolation and partial characterization of esters of trehalose from Corynebacterium ovis ( $C$. pseudotuberculosis). Chemistry and Physics of Lipids 23, 63-68.

IonedA, T., Lenz, M. \& Pudles, J. (1963). Chemical constitution of a glycolipid from Corynebacterium diphtheriae PW8. Biochemical and Biophysical Research Communications 13, 110-114. 
Kato, M. \& Asselineau, J. (1971). Chemical structure and biochemical activity of cord factor analogs : 6,6'dimycoloylsucrose and methyl 6-mycoloyl- $\alpha$-D-glucoside. European Journal of Biochemistry 22, 364 370.

Leclerc, C., Lamensans, A., Chedid, L., Drapier, J. C., Petit, J. F., Wietzerbin, J. \& Lederer, E. (1976). Non-specific immunoprevention of L-1210 leukemia by cord factor (6,6-dimycolate of trehalose) administered in a metabolisable oil. Cancer Immunology and Immunotherapy 1, 227-232.

Parant, M., Parant, F., Chedid, L., Drapier, J. C., Petit, J. F., Wietzerbin, J. \& Lederer, E. (1977). Enhancement of non-specific immunity to bacterial infection by cord factor. Journal of Infectious Diseases 135, 771-777.

Rouzer, C. A. \& Cerami, A. (1980). Hypertriglyceridemia associated with Trypanosoma brucei infection in rabbits: role of defective triglyceride removal. Molecular and Biochemical Parasitology 21, 31-38.

RUFF, M. R. \& GiFford, G. E. (1980). Purification and physico-chemical characterization of rabbit tumor necrosis factor. Journal of Immunology 125, 16711677.

Silberstein, D. S. \& David, J. R. (1986). Tumor necrosis factor enhances eosinophil toxicity to Schistosoma mansoni larvae. Proceedings of the National Academy of Sciences of the United States of America 83, 1055-1059

SILVA, C. L. \& IONEDA, T. (1977a). Isolation and identification of menaquinone and acylglycerols in the acetone-soluble lipids from Nocardia rhodochrous. Revista de microbiologia 8, 39-42.
Silva, C. L. \& Ioneda, T. $(1977 b)$. Purification and characterization of mononocardomycoloyl glycerol from Nocardia rhodochrous. Chemistry and Physics of Lipids 20, 217-222.

Silva, C. L., Gesztesi, J. L. \& IonedA, T. (1979). Trehalose mycolates from Nocardia asteroides, Nocardia farcinica, Gordona lentifragmenta and Gordona bronchialis. Chemistry and Physics of Lipids 24, 17-25.

StEWART-TulL, D. E. S. (1983). Immunologically important constituents of mycobacteria: adjuvants. In The Biology of the Mycobacteria, vol. 2, pp. 3-84. Edited by C. Ratledge \& J. Stanford. London: Academic Press.

SteWART-TULL, D. E. S. (1985). Immunopotentiating conjugates. Vaccine 3, 40-44.

Taverne, J., Dockrell, H. M. \& Playfair, J. H. L. (1981). Endotoxin-induced serum factor kills malaria parasites in vitro. Infection and Immunity 33, 8390.

Thomas, D. W., Matida, A. K., Silva, C. L. \& IONEDA, T. (1979). Esters of trehalose from Corynebacterium diphtheriae: a modified purification procedure and studies on the structure of their constituent hydroxylated fatty acids. Chemistry and Physics of Lipids 23, 267-282.

Torti, F. M., Dieckmann, B., Beutler, B., Cerami, A. \& RingolD, G. M. (1985). A macrophage factor inhibits adipocyte gene expression: an in vitro model of cachexia. Science 229, 867-869.

YARKoNI, E., RAPP, H. J., POLONSKY, J. \& LEDERER, E. (1978). Immunotherapy with an intralesionally administered synthetic cord factor analogue. International Journal of Cancer 22, 564-569. 